Al-Bayyinah: Journal of Islamic Law-ISSN: 1979-7486 (p); 2580-5088 (e) Volume VI Number 1, pp. 111-124

\title{
IMPLEMENTASI NIKAH FASID DAN NIKAH BATIL (Studi Kasus KUA Kec. Cempa Kab. Pinrang)
}

\author{
Abdul Rahim \\ (Dosen Tetap STAIN Watampone, Sulawesi Selatan, Indonesia, \\ email: rahim_ilmi72@yahoo.co.id)
}

\section{Abstract}

Marriage fasid and marriage vanity is a form of unauthorized marriage in the eyes of the laws of law and religion. In fact now, many marriages are not in accordance with the procedure and do not meet the pillars and terms of the marriage. Just based on the same likes without seeing the terms and pillars to be met before marriage. Therefore, to overcome such a thing required a principle of selectivity that is a principle in a marriage when a person who wants to marry it must select first with whom he may marry and with whom he is prohibited to marry.

\section{Kata Kunci: Nikah Fasid, Nikah Batil}

\section{PENDAHULUAN}

Hampir semua makhluk ciptaan Allah swt di dunia ini jika hendak memperbanyak keturunannya harus melalui proses pernikahan, begitu pula dengan manusia. Sebagai salah satu mahkluk Allah yang diberi kelebihan dibanding makhluk lainnya dalam melangsungkan keturunan harus melalui wadah pernikahan yang sah.

Allah tidak menjadikan manusia seperti makhluk lainnya yang hidup bebas mengikuti nalurinya dan berhubungan secara anarkhi tanpa aturan, demi menjaga kehormatan dan martabat kemuliaan manusia, Allah mengadakan hukum sesuai dengan martabatnya, sehingga hubungan antara laki-laki dengan perempuan diatur secara terhormat dan berdasarkan rasa saling 
meridhai dengan upacara ijab kabul, sebagai lambang adanya rasa ridha-meridhai dan dihadiri para saksi yang menyaksikan bahwa pasangan laki-laki dan perempuan itu telah saling terikat. Bentuk pernikahan telah memberikan jalan yang aman pada naluri seks, memelihara keturunan dengan baik dan menjaga kaum perempuan agar tidak laksana rumput yang bisa dimakan oleh binatang ternak dengan seenaknya. ${ }^{1}$

Sebagaimana firman Allah dalam QS An-Nisa(4):1

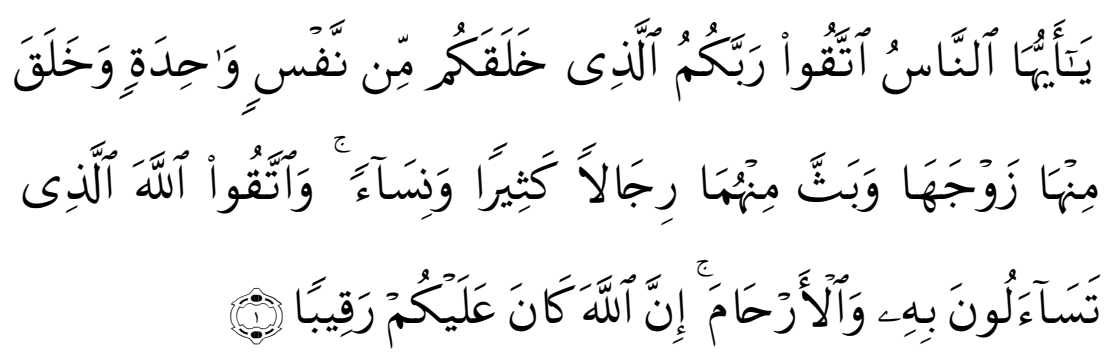

Terjemahnya:

Hai sekalian manusia, bertakwalah kepada Tuhanmu yang telah menciptakan kamu dari seorang diri, dan dari padanya, Allah menciptakan isterinya; dan dari pada keduanya Allah memperkembang biakkan laki-laki dan perempuan yang banyak. dan bertakwalah kepada Allah yang dengan (mempergunakan) nama-Nya kamu saling meminta satu sama lain dan (peliharalah) hubungan silaturrahim. Sesungguhnya Allah selalu menjaga dan mengawasi kamu. (An-Nisa:1) ${ }^{2}$

Manusia diciptakan Allah mempunyai naluri manusiawi yang perlu mendapatkan pemenuhan, salah satu jalan untuk memenuhi naluri manusia seperti penyaluran biologisnya yaitu didahului dengan perkawinan yang mengikuti ketentuanketentuan yang telah diatur oleh hukum agama ${ }^{3}$. Dalam Islam

\footnotetext{
${ }^{1}$ Rahman Ghazaly, Fiqh Munakahat, (Cet.1; Jakarta: Prenada Media, 2003), h.11

${ }^{2}$ Departemen Agama RI, Alqur'an dan Terjemahnya, (Bandung: Penerbit J-Art, 2005), h.78
} 
pernikahan merupakan sunnah Nabi, yang harus dicontoh oleh umatnya. Oleh karena itu, bagi pengikut Nabi Muhammad saw yang baik, hendaklah ia kawin, selain dari pada itu mencontohi tindak laku Nabi juga merupakan naluri kemanusiaan, kebutuhan rohani dan jasmani. Perkawinan disyariatkan supaya manusia mempunyai keturunan yang sah menuju kehidupan bahagia di dunia maupun di akhirat di bawah naungan cinta kasih dan ridha ilahi ${ }^{4}$.

Pernikahan disyariatkan oleh Allah swt dan Nabi saw sebagai jaminan untuk menghalalkan persetubuhan antara jenis kelamin yang berbeda, sebagaimana makhluk lainnya, untuk melanjutkan keturunan.

Jadi tujuan dari pernikahan menurut perintah Allah untuk memperoleh keturunan yang sah dalam masyarakat, dengan mendirikan rumah tangga yang damai dan teratur. Selain itu untuk memenuhi kebutuhan hidup jasmani dan rohani. ${ }^{5}$ Bukan hanya itu pernikahan merupakan suatu hal yang sangat prinsip dalam suatu kehidupan masyarakat, dan sangat dihormati aturan pelaksanaan, sehingga pelaksanaan perkawinan itu sesuai dengan norma dan prinsip yang telah disepakati bersama. ${ }^{6}$ Masalah pernikahan sangat penting, karena tidak hanya mengenai persoalan individunya semata, bukan hanya dari segi agama, tapi juga akan mempengaruhi masalah sosial dan hukum, dan salah satu aspek suksesnya pembangunan Indonesia adalah kestabilan di dalam kehidupan dan kesejahteraan keluarga. Maka dari itu, pernikahan juga diatur dalam perundang-undangan yang bersifat melindungi, mengatur dan mendidik.

Pernikahan yang sukses dalam rangka membangun rumah tangga yang bahagia merupakan idaman setiap orang, namun hanya sedikit orang yang mengetahui jalan dan sarana

${ }^{3}$ Syarifuddin Latif, Hukum Perkawinan Di Indonesia buku 1, (Cet.1; Watampone: Berkah Utami, 2010), h. 23

${ }^{4}$ Asro Sosroatmodjo,Wasit Aulawi, Hukum Perkawinan Di Indonesia (Cet.I; Jakarta: Bulan Bintang, 1975), h. 29

${ }^{5}$ Idris Ramulyo, Hukum Perkawinan Islam, Edisi 2, (cet.2; Jakarta: Bumi Aksara,1999), h. 26

${ }^{6}$ Abdul Manan, Aneka Masalah Hukum Perdata Islam di Indonesia, Ed .I (Cet.I; Jakarta: Kencana Media Group, 2006), h. 2

${ }^{7}$ Idris Ramulyo, op. cit., h. 20 
yang dapat menghantarkannya kepada kebahagiaan tersebut ${ }^{8}$. Namun tidak semuanya berjalan sesuai yang diharapkan, terkadang harus putus di tengah jalan, apakah sebab perceraian karena cerai talaq, cerai gugat atau cerai mati, maupun karena nikah fasid dan nikah batil. Berbicara mengenai nikah fasid dan nikah batil yang menjadi salah satu faktor perceraian maka dari itu untuk mengurangi tingginya angka perceraian karena nikah fasid dan nikah batil, maka diperlukan suatu pencegahan sebelum melakukan pernikahan itu.

Menurut hukum Islam, akad perkawinan adalah suatu perbuatan hukum yang sangat penting, mengandung akibatakibat serta konsekuensi-konsekuensinya sebagaimana yang telah ditetapkan oleh syariat Islam. Oleh karena itu, pelaksanaan akad pernikahan yang tidak sesuai dengan ketentuan yang telah ditetapkan syariat Islam adalah perbuatan yang sia-sia bahkan dipandang sebagai perbuatan yang melanggar hukum yang wajib dicegah oleh siapapun yang mengetahuinya. ${ }^{9}$

Kenyataannya sekarang, banyak masalah yang timbul karena pernikahan yang tidak sesuai dengan prosedur, yakni tidak memenuhi rukun dan syarat dari pernikahan itu. Hanya berlandaskan suka sama suka tanpa melihat syarat dan rukun yang harus dipenuhi sebelum melakukan penikahan. Maka dari itu, untuk mengatasi hal demikian diperlukan suatu asas selektivitas yakni suatu asas dalam suatu perkawinan bilamana seseorang yang hendak menikah itu harus menyeleksi lebih dahulu dengan siapa dia boleh menikah dan dengan siapa dia dilarangnya menikah. Dalam Islam mengenai asas selektifitas ada beberapa macam larangan menikah, selanjutnya asas legalitas ialah suatu asas dalam perkawinan, wajib hukumnya dicatat ${ }^{10}$ dalam hal ini tujuannya agar suatu pernikahan memiliki kekuatan hukum. Berkenan dengan asas legalitas, di negara Indonesia ada dua instansi atau lembaga yang diberi tugas untuk mencatat perkawinan dan perceraian serta ruju'. Adapun instansi atau lembaga yang dimaksud adalah Kantor Urusan Agama

${ }^{8}$ Abu Hafsh Usamah Bin Kamal Bin Abdir Razzaq, Panduan Lengkap Nikah Dari A Sampai Z, (Cet . 9; Bogor:Pustaka Ibnu Katsir, 2006), h.xi

${ }^{9}$ Abdul Manan, op.cit., h.42

${ }^{10}$ Idris Ramulyo, op.cit.,h.34 
Kecamatan untuk nikah, talak, dan ruju' bagi yang beragama Islam dan kantor catatan sipil yang beragama non Islam. ${ }^{11}$

Lembaga KUA (Kantor Urusan Agama) yang dalam hal ini pegawai pencatat nikah yang ditunjuk oleh pemerintah memiliki kewenangan dalam melakukan penyelektifan apakah calon laki-laki maupun calon wanita yang akan melangsungkan perkawinan sudah memenuhi rukun dan syarat atau tidak.

Dari konteks tersebut, salah satu masalah pernikahan yang sering timbul dikalangan masyarakat yakni nikah fasid dan nikah batil, meskipun masyarakat awam belum banyak mengetahui apa itu nikah fasid dan nikah batil. Tapi yang pasti nikah fasid dan nikah batil adalah suatu bentuk pernikahan yang tidak sah dimata hukum perundang-undangan dan agama. Dengan demikian diperlukan ketegasan dari lembaga pernikahan yang dalam hal ini biasa dikenal KUA (Kantor Urusan Agama). Jadi dalam tulisan ini penulis mencoba melihat peranan KUA dalam pencegahan nikah fasid dan nikah batil dengan studi kasusnya pada KUA Kecamatan Cempa.

\section{PEMBAHASAN}

Perkawinan merupakan pintu masuk untuk membentuk sebuah kehidupan baru dalam berumah tangga yaitu keluarga sakinah mawaddah warahmah. Sesuai ketentuan syariat Islam, dan peraturan perundang-undangan yang berlaku di Indonesia, khususnya di Kabupaten Pinrang. Demi kepentingan masyarakat agar dapat tercipta ketertiban, dalam hal perkawinan.

Namun kenyataan sekarang, terkadang ada oknum yang melanggar syariat Islam dan peraturan perundang-undangan dengan menjadikan suatu pernikahan itu bukanlah lagi sebagai suatu anjuran nabi yang bila dilakukan mendapat pahala akan tetapi menyababkan dosa jika pernikahan itu dilaksanakan.

Pernikahan yang memenuhi rukun dan syarat sesuai syariat Islam dan peraturan perundang-undangan adalah pernikahan yang diharapkan, namun ada pernikahan yang tidak memenuhi rukun dan syarat tetapi tetap dilaksanakan. Inilah yang menjadi masalah dalam hal pernikahan yang tidak boleh dibiarkan dan ini menjadi tanggung jawab bagi masyarakat

\footnotetext{
${ }^{11}$ Abdul Manan, op.cit., h. 14
} 
terkhusus bagi lembaga Kantor Urusan Agama (KUA) yang dalam hal ini Pegawai Pencatat Nikah (PPN) dan Pembantu Pegawai Pencatat Nikah (P3N)

Nikah fasid adalah nikah yang tidak memenuhi salah satu dari syarat-syarat nikah yang diatur dalam syariat Islam, sedangkan nikah batil adalah pernikahan yang tidak memenuhi rukun nikah yang ditetapkan dalam syariat Islam. ${ }^{12}$

Untuk lebih memahami, yang dapat dikategorikan sebagai nikah fasid antara lain, suami melakukan pernikahan, sedangkan ia tidak berhak melakukan akad nikah karena sudah mempunyai empat istri sekalipun salah satu dari ke empatnya itu dalam iddah. ${ }^{13}$

Seorang yang akan melakukan akad nikah namun terdapat larangan pernikahan baik larangan yang selamanya ataupun bersifat sementara.

Pernikahan yang melanggar batas umur pernikahan sebagaimana ditetapkan dalam pasal 7 Undang-Undang No 1 Tahun 1974, Dan pernikahan lainnya yang tidak memenuhi syarat-syarat pernikahan secara syariat Islam maupun peraturan perundang-undangan.

Adapun contoh dari nikah batil ialah pernikahan yang dilakukan tanpa kehadiran dari seorang wali baik wali nasab maupun wali hakim yang mewakili.

Pernikahan yang dilakukan dengan dasar penipuan yakni memalsukan identitas diri, mengaku dirinya masih lajang padahal masih terikat pernikahan dengan orang lain, atau memiliki suatu aib yang disembunyikan dari calon pasangannya maka hal ini dapat juga dikategorikan sebagai nikah fasid.

Pernikahan yang dianggap sah adalah pernikahan yang dilaksanakan menurut hukum masing-masing agama dan dicatat menurut peraturan perundang-undangan yang berlaku. Instansi atau lembaga yang diberi tugas untuk mencatat pernikahan ialah Kantor Urusan Agama kecamatan bagi yang beragama Islam.

Berkenan dengan tugas Kantor Urusan Agama kecamatan selaku pencatat pernikahan. Maka dari itu, Kantor Urusan Agama Kecamatan diharapkan mampu mencatat setiap

h. 13

${ }^{12}$ Syarifuddin Latif. Hukum perkawinan di Indonesia buku 2. op. cit, ${ }^{13}$ Ibid. 
pernikahan yang dilaksanakan di wilayahnya masing-masing dan mampu mengontrol terhadap kemungkinan kelalaian pencatatan pernikahan.

Kantor Urusan Agama Kecamatan Cempa dalam hal ini Kepala KUA Kecamatan Cempa selaku pegawai pencatat nikah dan pembantu pegawai pencatat nikah Kecamatan Cempa harus mampu mencatat dan mengontrol secara teliti tata cara atau proses pelaksanaan pencatatan nikah diwilayah Tanete Riattang. Adapun yang menjadi wilayah kerja KUA Kecamatan Cempa diantaranya Kelurahan Cempa, Desa Tanra Tuo. Desa Mangki, Desa Akkajang, Desa Tadampalie, dan Desa Wakka.

Setiap desa dan kelurahan memiliki pembantu pegawai pencatat nikah masing-masing untuk memudahkan pencatatan pernikahan. Maka dari itu, pegawai pencatat nikah dan pembantu pegawai pencatat nikah harus bekerja sama demi mewujudkan pernikahan yang sesuai dengan syariat dan peraturan perundangan di masyarakat.

Namun hal yang baik belum tentu berjalan dengan lancar, masalah yang ada dimasyarakat berkenan nikah fasid dan nikah batil sering di jumpai. Maka dari itu, untuk mencegah terjadinya nikah fasid dan nikah batil, pegawai pencatat nikah dan pembantu pegawai pencatat nikah harus memiliki pengetahuan luas tentang pernikahan termasuk nikah fasid dan nikah batil.

\section{Pendapat Mengenai Nikah Fasid Dan Nikah Batil}

Berdasarkan hasil wawancara dengan Kepala KUA Kecamatan Cempa, H. Anwar,

"Nikah fasid dan nikah batil adalah pernikahan yang tidak sesuai syariat agama dan juga tidak didukung oleh undang-undang negara kita. Termasuk nikahyang tidak mendatangkan walinya sesuai yang berhak menjadi wali, sering juga masih ada halangan yang tidak bisa nikah seperti perempuan yang masih punya suami namun belum talak meski telah lama berpisah. Kemudian masyarakat tersebut mengambil jalan pintas yang dianggap sehingga melakukan hal tersebut."14

${ }^{14}$ H.Anwar, Wawancara. Kantor Urusan Agama Kecamatan Cempa, Rabu, Tanggal 22, Mei, 2016 
Dari hasil wawancara, penulis dapat menyimpulkan bahwa Pegawai Pencatat Nikah dan Pembantu Pegawai Pencatat Nikah telah mengetahui bahwa nikah fasid dan nikah batil adalah dua bentuk pernikahan yang tidak sah, tidak sesuai agama dan aturan, namun belum ada kejelasan dari perbedaan keduanya.

\section{Perkara Mengenai Nikah Fasid Dan Nikah Batil Yang Terdaftar Dalam Kantor Urusan Agama Kecamatan Cempa}

Menurut H. Anwar mengenai perkara nikah fasid dan nikah batil dalam KUA Kecamatan Cempa

"Selama ini belum ada pernikahan fasid maupun batil yang terdaftar di KUA, namun ada orang yang datang ke Kantor Urusan Agama ini meminta surat nikah padahal nikahnya bukan disini, seperti nikahnya Rugayyah. Dalam hal ini KUA tidak memberikan surat nikah tanpa melalui persyaratan yang lengkap seperti ada

1. Pengantar dari lurah,

2. Menjelaskan status seseorang itu jejaka atau perawan

3. Dilengkapi keterangan orang tua untuk mengetahui wali yang bisa mewakili atau dinikahkan oleh walinya atau kepada yang diserahkan disertai keterangan wali yang lengkap. $^{15}$

Jadi, KUA Kecamatan Cempa belum pernah melakukan pencatatan pernikahan yang bermasalah dalam hal ini termasuk nikah fasid dan nikah batil. Pegawai pencatat nikah di KUA Kecamatan Cempa selalu memberikan nasehat dan bimbingan bagi calon pengantin.

${ }^{15}$ H. Anwar, Wawancara. Kantor Urusan Agama Kecamatan Cempa, Rabu, Tanggal 22, Mei, 2016. 


\section{Bentuk Nikah Fasid Dan Nikah Batil Yang Pernah Terjadi Di Kantor Urusan Agama Kecamatan Cempa}

Menurut H. Anwar. "nikah fasid yang sering terjadi dan kejadian ini belum lama terjadi yakni ingin menikah namun masih dalam masa iddah. Dalam hal ini KUA tidak mau terlibat dan tidak akan menikahkanya.

Dari hasil wawancara, penulis dapat menyimpulkan bahwa belum ada nikah fasid dan nikah batil yang pernah terdaftar di KUA Kecamatan Cempa, namun ada orang-orang yang ingin melakukan nikah fasid seperti merencanakan pernikahan yang masih berada dalam masa iddah dan meminta surat nikah yang tidak sesuai prosedur.

4. Peranan Kantor Urusan Agama Kecamatan Cempa dalam mencegah nikah fasid dan nikah batil

Menurut H. Anwar, "peranan Kantor Urusan Agama disini untuk mencegah terjadinya nikah fasid dan nikah batil ialah memberikan sosialisasi kepada masyarakat mengenai pensyaratan-pensyaratan tentang rukun dan syarat nikah",16

Dari wawancara diatas, penulis dapat menyimpulkan bahwa peranan KUA untuk mencegah nikah fasid dan nikah batil adalah memberikan sosialisasi tentang tata cara dan syaratsyarat yang harus dipenuhi masyarakat.

5. Prosedur Pencegahan Nikah Fasid Dan Nikah Batil Di KUA Kecamatan Cempa

Menurut H. Anwar, "Jika pernikahan yang belum terdaftar di KUA, prosedur pencegahannya hanya sebatas memberikan arahan tentang perlengkapan pencatatan nikah. "17

6. Kendala yang sering dihadapi dalam pencatatan nikah

Menurut H. Anwar, "kendala pencatatan pernikahan terletak pada kedua calon pengantin yakni apabila kedua belah pihak ada sangkutan. Calon mempelai laki-laki ingin menikah namun masih

${ }^{16}$ H. Anwar, Wawancara. Kantor Urusan Agama Kecamatan Cempa, Rabu, Tanggal 22, Mei, 2016.

${ }^{17}$ H. Anwar, Wawancara. Kantor Urusan Agama Kecamatan Cempa, Rabu, Tanggal 22, Mei, 2016 
mempunyai istri dan belum ada bukti surat talak dari pengadilan agama. Begitu pula dengan calon mempelai perempuan yang sudah lama pisah namun belum ada bukti talak yang menjadi kendala tidak ada surat talak dikarenakan karena pernikahan pertamanya memang tidak mempunyai bukti surat nikah jadi tidak bisa mengurus perceraiannya di pengadilan agama. Kendala lainnya bukti surat talaknya baru keluar satu minggu namun sudah menentukan tanggal pernikahannya dan itu tidak memenuhi syarat karena masih berada dalam masa iddah dan dengan kendala itu semua KUA tidak akan mencatat pernikahannya dan KUA tidak mau terlibat. Kalau kendala secara materiil tidak jadi masalah asalkan ada keterangan dari kelurahan." 18

Dari wawancara diatas, penulis dapat menyimpulkan bahwa kendalapencatatan pernikahan terletak pada keadaaan kedua mempelai yang belum memenuhi syarat-syarat pernikahan, status dari kedua mempelai harus jelas agar tidak terjadi yang namanya nikah fasid dan nikah batil.

7. Konsekuensi Bagi Orang Yang Melakukan Nikah Fasid Dan Nikah Batil

Menurut Ruslan, "konsekuensinya adalah pernikahannya tidak dicatat dan ditolak pelaksanaan pernikahannya oleh KUA Kecamatan Cempa." 19

Jika setelah berlangsungnya akad nikah dan diketahui adanya larangan menurut hukum syariat maupun peraturan perundang-undangan tentang pernikahan, maka pernikahan itu dapat dibatalkan.

\section{Pencegahan Atau Pembatalan Nikah Fasid Dan Nikah Batil Pada KUA Kecamatan Cempa}

Menurut H. Anwar, "sebenarnya bukan pencegahan tapi lebih kepada penolakan, KUA menolak untuk mencatat pernikahannya karena belum memenuhi syarat

\footnotetext{
${ }^{18}$ H.Anwar, Wawancara. Kantor Urusan Agama Kecamatan Cempa, Rabu, Tanggal 22, Mei, 2016

${ }^{19}$ Ruslan, Wawancara.Kelurahan Cempa, Kecamatan Cempa, Rabu Tanggal 24, juli, 2016
} 
dan rukun pernikahan secara syariat maupun perundangundangan., 20

\section{Yang diperlukan dalam hal Pencatatan Nikah}

Menurut H. Anwar yakni :

a. pengantar dari kelurahan yang bersangkutan

b. rekomendasi dari tempat tinggal

c. poto kedua calon mempelai. ${ }^{21}$

\section{Alasan Orang-Orang Melakukan Nikah Fasid Dan Nikah Batil}

Menurut H. Anwar, "alasan orang-orang ingin melakukan nikah fasid dan nikah batil karena kurangnya pengetahuan masyarakat tentang syarat-syarat keabsahan nikah itu sendiri dan keinginan mereka unutk segera menikah, menetapkan waktu semaunya tanpa mempertimbangkan terlebih dahulu kelengkapan persiapan pernikahannya." 22

Dari hasil wawancara diatas, penulis dapat menyimpulkan bahwa alasan-alasan orang melakukan nikah fasid dan nikah batil ialah karena kurangnya pengetahuan masyarakat tentang syarat dan rukun pernikahan yang tidak boleh disepelekan karena akan menyebabkan tidak sahnya nikah.

Dan kondisi pula yang membuat orang-orang melakukan nikah fasid dan nikah batil, seperti hamil diluar nikah dan meskipun syaratnya ada yang belum terpenuhi tapi terpaksa pernikahannya dilaksanakan.

Setelah mengetahui alasan-alasan orang melakukan nikah fasid dan nikah batil, maka pegawai pencatat nikah dan pembantu pegawai pencatat nikah KUA Kecamatan Cempa melakukan inisiatf atau cara agar berperan aktif dalam pencegahan nikah fasid dan nikah batil.

${ }^{20}$ H.Anwar, Wawancara. Kantor Urusan Agama Kecamatan Cempa, Rabu, Tanggal 22, Mei, 2016

${ }^{21}$ H. Anwar., Wawancara. Kantor Urusan Agama Kecamatan Cempa, selasa, Tanggal 23, juli, 2016

${ }^{22}$ H.Anwar, Wawancara. Kantor Urusan Agama Kecamatan Cempa, Rabu, Tanggal 22, Mei, 2016 


\section{KESIMPULAN}

Nikah fasid ialah nikah yang tidak memenuhi syaratsyarat sahnya untuk melakukan pernikahan. Seperti pernikahan yang dilakukan antara dua orang yang mempunyai hubungan darah dalam garis keturunan dan apabila pernikahan itu terdapat larangan pernikahan baik bersifat sementara atau selamanya. Nikah fasid itu bisa juga terjadi apabila didalam pernikahan tersebut ada unsur penipuan. Seperti seorang laki-laki ingin menikahi seorang perempuan namun laki-laki tersebut menyembunyikan identitas aslinya atau laki-laki tersebut memiliki aib. Sedangkan pada dasarnya pernikahan itu harus terang-terangan, harus jujur mengenai keadaan yang sebenarnya diantara pihak laki-laki dan pihak perempuan.

Nikah batil ialah pernikahan yang tidak memenuhi salah satu rukun dari pernikahan. seperti pernikahan yang dilakukan tanpa kehadiran seorang wali baik wali nasab maupun wali hakim yang ditunjuk oleh wali nasab untuk menggantikannya.

Peranan KUA (Kantor urusan agama) Kecamatan Cempa dalam mencegah terlaksananya nikah fasid dan nikah batil ini adalah sosialisasi kepada masyarakat tentang rukun dan syarat pernikahan yang sah dan memantau langsung ke masyarakat agar tidak terjadi pernikahan yang dilarang oleh syariat dan undang-undang pernikahan.

Mengenai prosedur pencegahan nikah fasid dan nikah batil yang telah terdaftar yakni Pencegahan pernikahan diajukan ke pengadilan agama dalam daerah hukum tempat pernikahan akan dilangsungkan oleh mereka yang dapat mencegah pernikahan. Mereka yang melakukan pencegahan pernikahan harus memberitahukan pula kepada pegawai pencatat nikah atau pembantu pegawai pencatat nikah yang bersangkutan tentang usaha pencegahannya. Dan pegawai pencatat nikah atau pembantu pegawai pencatat nikah harus memberitahukan kepada masing-masing calon mempelai. 


\section{DAFTAR PUSTAKA}

Manan, Abdul, Aneka Masalah Hukum Perdata Islam Di Indonesia, Ed. I, Cet. I; Jakarta: Kencana Media Group, 2006

Rahman, Abdur, Terjemahan Buku The Islamic Law, Alih Bahasanya Usman Effendi, Abdul Khaliq,Inilah Syariah Islam.Cet 1: Jakarta :Pustaka Panji Mas: 1990

Abiding, Slamet, Aminuddin, FiqihMunakahatI, CetI: Bandung: Pustaka Setia,1999

Abu bakr jabir al-jazairi, Minhajul Muslim, diterjemahkan oleh Fadhli Bahri, Ensiklopedi Muslim, Cet. 1;Jakarta Timur : Darul Falah. 2000

Agama R.I. Departemen, Kompilasi Hukum Islam Di Indonesia. Jakarta: Direktorat Jendral Pembinaan Kelembagaan Keagamaan Islam, 2000

Amir, syarifuddin, Garis-Garis Besar Fiqh, Cet. 2: Jakarta; Kencana. 2003

Amrin," Tingkat Perceraian Akibat Tidak Terpenuhi Nafkah Bathin Istri Oleh Suami”, Skripsi, (Watampone :program sarjana STAIN Watampone, 2011

Departemen Agama R.I, Pedoman Pembantu Pegawai Pencatat Nikah, (Jakarta; Direktorat Jenderal Bimbingan Masyarakat Islam Dan Urusan Haji. 1992

Bandung: CV Penerbit Al-Jumanatul 'Ali Art/ J-Art, 2005

Direktorat Jenderal Pembinaan Kelembagaan Agama Islam Departemen Agama, Ilmu Figh, Cet. 2, Jilid 2: Jakarta;Cv Yulind, 1985

Ghazaly, Rahman Abd, Fiqh Munakahat. Cet.I; Jakarta: Prenada Media, 2003

H, Dani, Kamus Ilmiah Populer Edisi Lengkap. Cet.I; Surabaya: Gita Media, 2006 
Hasan, Ali, Masail Fiqhiyah Al-Haditsah Pada MasalahMasalah Kontemporer Hukum Islam, Cet. 3:Jakarta; Raja Grafindo Persada, 1998

Imam Hafidz Al Musnaf Al Mut'qan Abi Daud Sulaiman Ibnu Asy'as, Sunanul Abu Daud, Cet. 2;Kairo: Warul Hadits. 1988

Latif, Syarifuddin, Fiqhi Munakahat I, :Watampone:Fakultas Syariah IAIN Alauddin 1989

Cet.I; Watampone: Berkah Utami, 2010

, Hukum Perkawinan Di Indonesia Buku 2.

Cet.I; Watampone: Berkah Utami, 2010

,Status Hukum Pernikahan Wanita Hamil Di

Luar Nikah Dan Anaknya Perspektif Hukum Adat Dan Hukum Islam, Cet. I ;Yogyakarta: Trust Media Publishing, 2012

M, Nuhrison, Optimalisasi Peran KUA Melalui Jabatan Fungsional Penghulu. Cet. I; Jakarta: Puslitbang Kehidupan Keagamaan, 2007

Nasution, Khoiruddin, Islam Tentang Relasi Suami Dan Istri, Cet. I; Yogyakarta: ACAdeMIA+Tazzafa, 2004

Notosusanto, Organisasi Dan Jurisprudensi Peradilan Agama Di Indonesia,:Jogjakarta: Gadjah Mada, 1963

Razzaq Bin Abdir, Bin Usamah, Hafsh Abu, Paduan Lengkap Dari A Sampai Z, Cet.VIII; Bogor: Pustaka Ibnu, 2006

Romulyo, Idris, Hukum Perkawinan Islam, Ed. 2, Cet. 2; Jakarta: Bumi Aksara,1999

Soimin, Soedaryo. Hukum Orang dan Keluarga ,Cet. I; Jakarta; Sinar Grafika, 1992

Sosroatmodjo, Asro. Aulawi, wasit. Hukum Perkawinan Di Indonesia Cet. I; Jakarta: Bulan Bintang, 1975

Thalib, Muhammad, Manajemen Keluarga Sakinah. Cet.2;Yogyakarta: Pro-U Media. 2008 